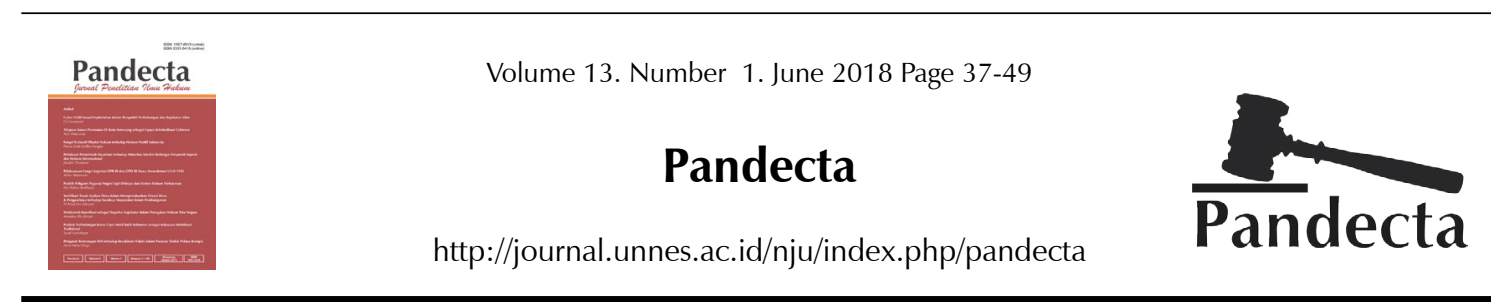

\title{
Self-Rescpect dan Kesadaran Hukum Pejabat Tata Usaha Negara Menuju Keadilan
}

\author{
Untoro $\bowtie$
}

Fakultas Hukum Universitas Islam Jakarta

DOI: http://dx.doi.org/10.15294/pandecta.v13i1.7856

\begin{abstract}
Article Info
Abstrak

Article History:

Received : December 2016

Accepted: June 2018

Penelitian ini bertujuan untuk menganalisis bagaimana self respect dan kesadaran

hukum dari Pejabat Tata Usaha Negara serta pengaruhnya terhadap putusan Peradilan Tata Usaha Negara yang telah berkekuatan hukum tetap. Metode penelitian yang digunakan dengan pendekatan yuridis normatif (doctrinal approach). Hasil

Keywords:

Legal awareness;

self respect; penelitian ini menunjukkan bahwa ada tiga faktor yang menjadi penyebab belum optimalnya self respect dan kesadaran hukum Pejabat Tata Usaha Negara terhadap putusan Peradilan Tata Usaha Negara yang telah berkekuatan hukum tetap yaitu: justice regulasi eksekusi putusan Peradilan Tata Usaha Negara, kualitas putusan Peradilan Tata Usaha Negara, budaya hukum Pejabat Tata Usaha Negara. Selain itu, self respect dan kesadaran hukum Pejabat Tata Usaha Negara terhadap putusan Peradilan Tata Usaha Negara yang telah berkekuatan hukum tetap berpengaruh dalam mewujudkan keadilan.
\end{abstract}

\begin{abstract}
This study aims to analyze how the self respect and legal awareness of the State Administrative Officers as well as its influence on the decision of the State Administrative Court which has a permanent legal force. The research method used with normative juridical approach (doctrinal approach). The results of this study indicate that there are three factors that cause the not yet optimal self respect and legal awareness of the State Administrative Officer against the decision of the State Administrative Court which has a permanent legal force, namely: the execution of the decision of the State Administrative Court, the quality of the decision of the State Administrative Court, legal culture of the State Administrative Officer. In addition, the self respect and legal awareness of the State Administrative Officer of the State Administrative Court ruling which has the legal power remains influential in realizing justice.
\end{abstract}




\section{Pendahuluan}

Keberadaan Peradilan Tata Usaha Negara tidak dapat dipisahkan dari Indonesia sebagai negara hukum, karena eksistensinya merupakan salah satu ciri dari negara hukum. Diharapkan perannya dalam penegakan hukum administrasi yang berfungsi sebagai kontrol yuridis eksternal penyelenggaraan pemerintahan. Sebagai lembaga kontrol yuridis eksternal belum menunjukkan hasil yang optimal. Data menunjukkan masih adanya permohonan eksekusi oleh penggugat kepada Ketua Pengadilan Tata Usaha Negara. Hal ini menunjukkan ketidakpatuhan pejabat tata usaha negara terhadap putusan Peradilan Tata Usaha Negara.

Dalam posisinya sebagai lembaga pengawas (judicial control) Peradilan Tata Usaha Negara mempunyai ciri-ciri pertama, pengawasan yang dilakukan bersifat ekstern karena merupakan lembaga yang berada di luar kekuasaan administrasi negara (bestuur); kedua, bersifat a posteriori pengawasan yang dilakukan lebih menekankan pada tindakan represif atau, yang dilakukan sesudah terjadinya perbuatan yang dikontrol. Ketiga, kontrol segi hukum artinya pengawasan dilakukan pada segi legalitas atau dengan menilai dari segi hukumnya. ( Ridwan HR, 2014: 297).

Sebagai negara hukum yang berdasarkan Pancasila dan Undang-Undang Dasar Negara Republik Indonesia Tahun 1945 sudah saatnya untuk mengoptimalkan penegakan hukum administrasi. Pengawasan terhadap tindakan pemerintah dimaksudkan agar pemerintah dalam menjalankan aktivitasnya sesuai dengan norma-norma hukum. Sehingga pemerintah dalam menyelenggarakan pemerintahannya senantiasa didasarkan kepada keadilan. (M. Makhfudz. 2017. Pemerintahan Reformis Tapi Tidak Reformis). Termasuk di dalamnya adalah melaksanakan putusan Pengadilan Tata Usaha Negara yang telah berkekuatan hukum tetap oleh pejabat tata usaha negara, tanpa didahului permohonan pelaksanaan putusan oleh penggugat kepada Ketua Pengadilan Tata Usaha Negara.

Kewajiban yang harus dilaksanakan oleh pejabat tata usaha negara sebagai bentuk realisasi dikabulkannya gugatan oleh
Pengadilan Tata Usaha Negara meliputi: pencabutan Keputusan Tata Usaha Negara yang bersangkutan, maksudnya adalah Keputusan Tata Usaha Negara yang disengketakan; pencabutan Keputusan Tata Usaha Negara yang bersangkutan dan menerbitkan Keputusan Tata Usaha Negara yang baru; penerbitan Keputusan Tata Usaha Negara dalam hal gugatan didasarkan pada Pasal 3 atau fiktif negatif.

Kewajiban ini yang harus disikapi oleh pejabat tata usaha negara sebagai bentuk penegakan hukum dalam hukum administrasi. Namun demikian dalam prakteknya tidak semua putusan Pengadilan Tata Usaha Negara yang telah berkekuatan hukum tetap dilaksanakan oleh pejabat tata usaha negara.

Sebagaimana dinyatakan oleh P. Nikolai dan kawan-kawan, De bestuursrechtelijke handhavings-middelen omvatten (1) het toezich dat bestuursorganen kunnen uitoefenen op de naleving van de bij of krachtens de wet gestelde voorschriften en van de bij besluit individueel opgeledge verplichtingen, en (2) de toepassing van bestuursrechtelijke sanctie bevoegdheden artinya: Sarana penegakan Hukum Administrasi Negara berisi pengawasan bahwa organ pemerintahan dapat melaksanakan ketaatan pada atau berdasarkan undang-undang yang ditetapkan secara tertulis dan pengawasan terhadap keputusan yang meletakkan kewajiban kepada individu, dan penerapan kewenangan sanksi pemerintahan. (Ridwan HR, 2014: 296).

Penelitian ini akan membahas tentang bagaimana Self respect dan kesadaran hukum dari Pejabat Tata Usaha, serta pengaruhnya terhadap putusan Peradilan Tata Usaha Negara yang telah in kracht van gewijsde bagi terwujudnya keadilan.

\section{Metode Penelitian}

Penelitian ini adalah penelitian hukum normatif yang berusaha mencari jawaban terhadap permasalahan tentang pelaksanaan putusan Peradilan Tata Usaha Negara yang telah berkekuatan hukum tetap. Penelitian hukum normatif (yuridis normatif) dilakukan dengan meneliti bahan hukum pustaka atau penelitian kepustakaan (library research). Studi kepustakaan dilakukan dengan men- 
gumpulkan bahan hukum sekunder berupa data permohonan eksekusi di Pengadilan Tata Usaha Negara Jakarta, Pengadilan Tata Usaha Negara Bandung dan Pengadilan Tata Usaha Negara Yogyakarta. Di samping itu dengan mempelajari buku-buku, jurnal yang berhubungan dengan objek penelitian. Data sekunder yang diperoleh untuk selanjutnya dianalisis secara deskriptif kualitatif disusun secara sistematis, logis serta terhadap data yang diperoleh dilakukan penafsiran.

\section{Hasil Penelitian dan Pembahasan}

Self respect dan kesadaran hukum dari Pejabat Tata Usaha Negara terhadap putusan Peradilan Tata Usaha Negara yang telah in kracht van gewijsde.

Sebelum revisi Undang-Undang Nomor 5 Tahun 1986 tentang Peradilan Tata Usaha Negara, eksekusi putusan Peradilan Tata Usaha Negara dipengaruhi oleh asas self respect dan sistem floating execution yaitu kewenangan melaksanakan putusan pengadilan yang sudah berkekuatan hukum tetap, sepenuhnya diserahkan kepada badan atau pejabat yang berwenang, tanpa adanya kewenangan bagi Peradilan Tata Usaha Negara menjatuhkan sanksi. Setelah revisi terhadap Undang-Undang Nomor 5 Tahun 1986 tentang Peradilan Tata Usaha Negara, proses pelaksanaan putusan Peradilan Tata Usaha Negara mempergunakan sistem fixed execution, yaitu eksekusi yang pelaksanaannya dapat dipaksakan oleh pengadilan melalui saranasarana pemaksa yang diatur dalam peraturan perundang-undangan. (Tjandra, 2009: 243).

Putusan Peradilan Tata Usaha Negara yang telah berkekuatan hukum tetap atau in kracht van gewijsde wajib dilaksanakan oleh pihak yang dikalahkan dalam perkara yang bersangkutan. Apabila pihak tergugat yang dikalahkan maka tergugat wajib melaksanakan putusan Peradilan Tata Usaha Negara dengan sukarela.Tidak dilaksanakannya putusan Peradilan Tata Usaha Negara yang telah berkekuatan hukum tetap dengan sukarela, maka sebagai solusi yang diberikan oleh Undang-Undang Nomor 51 Tahun 2009 tentang Perubahan Kedua Undang-Undang Nomor 5 Tahun 1986 tentang Peradilan Tata
Usaha Negara adalah memberikan kesempatan kepada pihak penggugat mengajukan permohonan kepada ketua pengadilan agar memerintahkan tergugat melaksanakan putusan pengadilan tersebut. Hal seperti ini menurut penulis adalah merupakan awal dari eksekusi. Jadi adanya eksekusi karena tidak dilaksanakannya putusan peradilan yang telah berkekuatan hukum tetap secara sukarela, sehingga penggugat mengajukan permohonan kepada Ketua Pengadilan Tata Usaha Negara agar memerintahkan tergugat melaksanakan putusan pengadilan tersebut. Mengingat bahwa secara filosofis keberadaan Peradilan Tata Usaha Negara dalam konstruksi negara hokum untuk memberikan perlindungan hak perseorangan maupun hak masyarakat umum sehingga tercapai keserasian, keselarasan, keseimbangan, dinamisasi, harmonisasi hubungan antara warga Negara dengan Negara dalam hal ini pejabat tata usaha Negara (Rumadan, 2012: 436).

Ada dua kriteria putusan Peradilan Tata Usaha Negara telah berkekuatan hukum tetap. Pertama, penggugat dan tergugat telah menyatakan menerima terhadap putusan pengadilan, padahal penggugat dan tergugat mempunyai hak untuk mengajukan pemeriksaan di tingkat banding. Kedua, sampai lewat tenggang waktu yang telah ditentukan, penggugat dan tergugat tidak mengajukan permohonan pemeriksaan di tingkat banding atau kasasi. (Mahkamah Agung, 2011: 517).

Ada beberapa konsekuensi-konsekuensi yuridis putusan hakim Pengadilan Tata Usaha Negara yang telah berkekuatan hukum tetap, sebagaimana dinyatakan oleh Paulus Effendi Lotulung:

1. Sengketa yang bersangkutan telah berakhir dan tidak ada lagi upaya hukum biasa yang dapat ditempuh oleh para pihak yang berperkara.

2. Putusan tersebut mempunyai daya mengikat bagi setiap orang atau bersifat erga omnes.

3. Putusan tersebut merupakan akta autentik yang mempunyai daya kekuatan pembuktian sempurna.

4. Putusan tersebut mempunyai kekuatan eksekutorial yang berarti bahwa isi 
putusan tersebut dapat dilaksanakan. Jika perlu dengan upaya paksa apabila pihak yang dikalahkan tidak mau melaksanakan dengan sukarela isi putusan yang bersangkutan. (Permana, 2015: 3).

Asas hukum mengatakan Res judicata pro veritate habetur yang berarti putusan (dalam arti luas termasuk di dalamnya penetapan) pengadilan adalah hukum, sehingga jika ada pihak-pihak yang tidak patuh atau tidak bersedia melaksanakan putusan/penetapan pengadilan secara sukarela dengan berbagai alasan yang tidak sesuai dengan hukum sama dengan melawan hukum. Bahkan peninjauan kembali yang merupakan upaya hukum luar biasa tidak dapat menunda pelaksanaan putusan pengadilan yang telah berkekuatan hukum tetap. Hal ini menunjukka bahwa putusan badan peradilan merupakan norma yang ditujukan kepada peristiwa konkrit yang disebut norma khusus. (Bakti, 2016: 61).

Eksekusi merupakan tindakan hukum yang dilakukan oleh pengadilan terhadap pihak yang kalah dalam sebuah perkara. Ini merupakan aturan dan tata cara lanjutan dari sebuah proses pemeriksaan perkara. (Neno, 2006: 138). Artinya tindakan hukum tersebut diambil karena putusan Peradilan Tata Usaha Negara tidak dilaksanakan secara sukarela oleh pihak tergugat.

Adanya permohonan dari penggugat kepada Ketua Pengadilan Tata Usaha Negara agar memerintahkan tergugat melaksanakan putusan pengadilan, menunjukkan belum optimalnya penghormatan (self respect) dan kesadaran pejabat tata usaha negara terhadap putusan Peradilan Tata Usaha Negara. Tiga faktor yang menjadi penyebab tidak dipatuhinya putusan Peradilan Tata Usaha Negara, yaitu: pertama regulasi eksekusi putusan Peradilan Tata Usaha Negara. Kedua, Kualitas putusan Peradilan Tata Usaha Negara. Ketiga, budaya hukum pejabat tata usaha negara/pemerintah. (Heriyanto, 2014: 187189).

Regulasi lembaga paksa berupa uang paksa (dwangsom) dan sanksi administratif sebagaimana diatur dalam Pasal 116 Undang-Undang Nomor 51 Tahun 2009 tentang perubahan kedua Undang-Undang Nomor 5 Tahun 1986 tentang Peradilan Tata Usaha Negara sudah cukup baik dan tegas. Terhambat dalam implementasinya karena belum adanya peraturan pelaksananya.Sehingga bagi hakim tidak ada keberanian untuk menerapkan sanksi uang paksa dan sanksi administratif.

Kualitas putusan Peradilan Tata Usaha Negara berkaitan dengan penalaran hukum, sebab penalaran hukum yang lemah akan mempengaruhi kualitas putusan.yang kurang atau tidak baik dan sebaliknya penalaran hukum yang kuat akan menjadikan putusan pengadilan menjadi baik. Pelaksanaan putusan Peradilan Tata Usaha Negara berbeda dengan pelaksanaan putusan pidana dan putusan perdata. Jika dalam amar pejabat tata usaha negara diperintahkan untuk mencabut Keputusan Tata Usaha Negara yang disengketakan dan menerbitkan Keputusan Tata Usaha Negara yang baru, maka yang harus dilakukan sebelum melaksanakan putusan Pengadilan Tata Usaha Negara adalah membaca dengan seksama pertimbangan dalam putusan tersebut. Putusan yang berkualitas berpengaruh terhadap kepatuhan Pejabat Tata Usaha Negara untuk mematuhi dan melaksanakan putusan Putusan Peradilan Tata Usaha Negara.

Ciri khas penalaran hukum sebagai kegiatan berpikir problematis tersistematis adalah

1. Penalaran hukum berupaya mewujudkan konsistensi dalam aturanaturan hukum dan putusan-putusan hukum. Dasar berpikirnya asas similia similibus, yaitu kasus yang sama harus diberikan putusan yang sama.

2. Penalaran hukum berupaya memelihara kontinuitas dalam waktu atau konsistensi historikal. Penalaran hukum akan mengacu pada aturanaturan hukum yang sudah terbentuk sebelumnya dan putusan-putusan hukum terdahulu sehingga menjamin stabilitas dan prediktabilitas.

3. Dalam penalaran hukum terjadi penalaran dialektika, yaitu menimbangnimbang klaim-klaim yang berlawanan 
dalam perdebatan pada pembentukan hukum, proses mempertimbangkan pandangan dan fakta yang diajukan para pihak dalam proses peradilan dan proses negosiasi. (Rivai, 2014: 93-94).

Lebih lanjut Shidarta, menambahkan enam langkah penalaran hukum:

1. Mengidentifikasi fakta-fakta untuk menghasilkan suatu struktur (peta) kasus yang sungguh-sungguh diyakini oleh hakim sebagai kasus yang riil terjadi;

2. Menghubungkan (mensubsumsi) struktur kasus tersebut dengan sumber-sumber hukum yang relevan, sehingga ia dapat menetapkan perbuatan hukum dalam peristilahan yuridis (legal term);

3. Menyeleksi sumber hukum dan aturan hukum yang relevan untuk kemudian mencari tahu kebijakan yang terkandung di dalam aturan hukum itu (the policies underlying those rules) sehingga dihasilkan suatu struktur atau peta aturan yang koheren;

4. Menghubungkan struktur aturan dengan struktur kasus;

5. Mencari alternatif-alternatif penyelesaian yang mungkin;

6. Menetapkan pilihan atas salah satu alternatif untuk kemudian diformulasikan sebagai putusan akhir.

Namun demikian terhadap putusan yang lemah dalam penalaran hukum tidak boleh menjadi penghalang untuk melaksanakan putusan Peradilan Tata Usaha Negara, hal ini karena terdapat asas yang menyatakan bahwa putusan hakim harus dianggap benar (res judicata pro). Budaya hukum adalah subbudaya (sub-culture) yang bertalian dengan penghargaan dan sikap tindak manusia terhadap hukum sebagai realitas sosial. Budaya hukum bertalian dengan struktur hukum dan substansi hukum. Penataan struktur hukum yang baik untuk menjalankan aturan hukum yang telah ditetapkan, dan kualitas substansi hukum yang baik tanpa didukung budaya hukum oleh orang-orang yang terlibat dalam sistem dan masyarakat maka penegakan hukum tidak berjalan efektif.
Pendapat lain menyatakan bahwa ada tiga faktor yang menyebabkan Pejabat Tata Usaha Negara tidak secara sukarela untuk mematuhi dan melaksanakan putusan Peradilan Tata Usaha Negara, yaitu:

1. Putusan yang telah berkekuatan hukum tetap tersebut tidak dapat dilaksanakan atau non executable.

2. Putusan yang telah berkekuatan hukum tetap tersebut dianggap tidak memenuhi rasa keadilan.

3. Tergugat telah memiliki "kepentingan" dengan pihak ketiga sehingga terikat untuk mempertahankan keputusan yang digugat tersebut.

Secara sederhana dapat digambarkan alur mulai dari putusan yang telah berkekuatan hukum tetap hingga permohonan eksekusi kepada Ketua Pengadilan Tata Usaha Negara berdasarkan ketentuan Pasal 116 Undang-Undang Nomor 51 Tahunn 2009 tentang Perubahan Kedua Undang-Undang Nomor 5 Tahun 1986 tentang Peradilan Tata Usaha Negara, sebagaimana terlihat pada Gambar 1.

Putusan yang dapat dilaksanakan adalah putusan yang telah memperoleh kekuatan hukum tetap. Asas yang gunakan dasar dalam pelaksanaan putusan PTUN yang telah berkekuatan hukum tetap adalah asas contrarius actus. Terhadap putusan pengadilan yang telah berkekuatan hukum tetap, ada dua kemungkinan yang terjadi yaitu tergugat melaksanakan putusan berarti secara sukarela melaksanakan putusan pengadilan yang telah berkekuatan hukum tetap. Kemungkinan kedua, tergugat tidak melaksanakan putusan pengadilan yang telah berkekuatan hukum tetap yang di dalamnya berisi kewajiban yang harus dilaksanakan menurut ketentuan Pasal 97 ayat (9) huruf a, b, c Undang-Undang Nomor 51 Tahun 2009 tentang Perubahan Kedua Undang-Undang Nomor 5 Tahun 1986 tentang Peradilan Tata Usaha Negara.

Dalam hal tergugat tidak melaksanakan kewajiban sebagaimana dimaksud oleh Pasal 97 ayat (9) huruf a maka, Keputusan Tata Usaha Negara yang disengketakan tidak mempunyai kekuatan hukum tetap lagi. Dalam hal tergugat tidak melaksanakan kewa- 


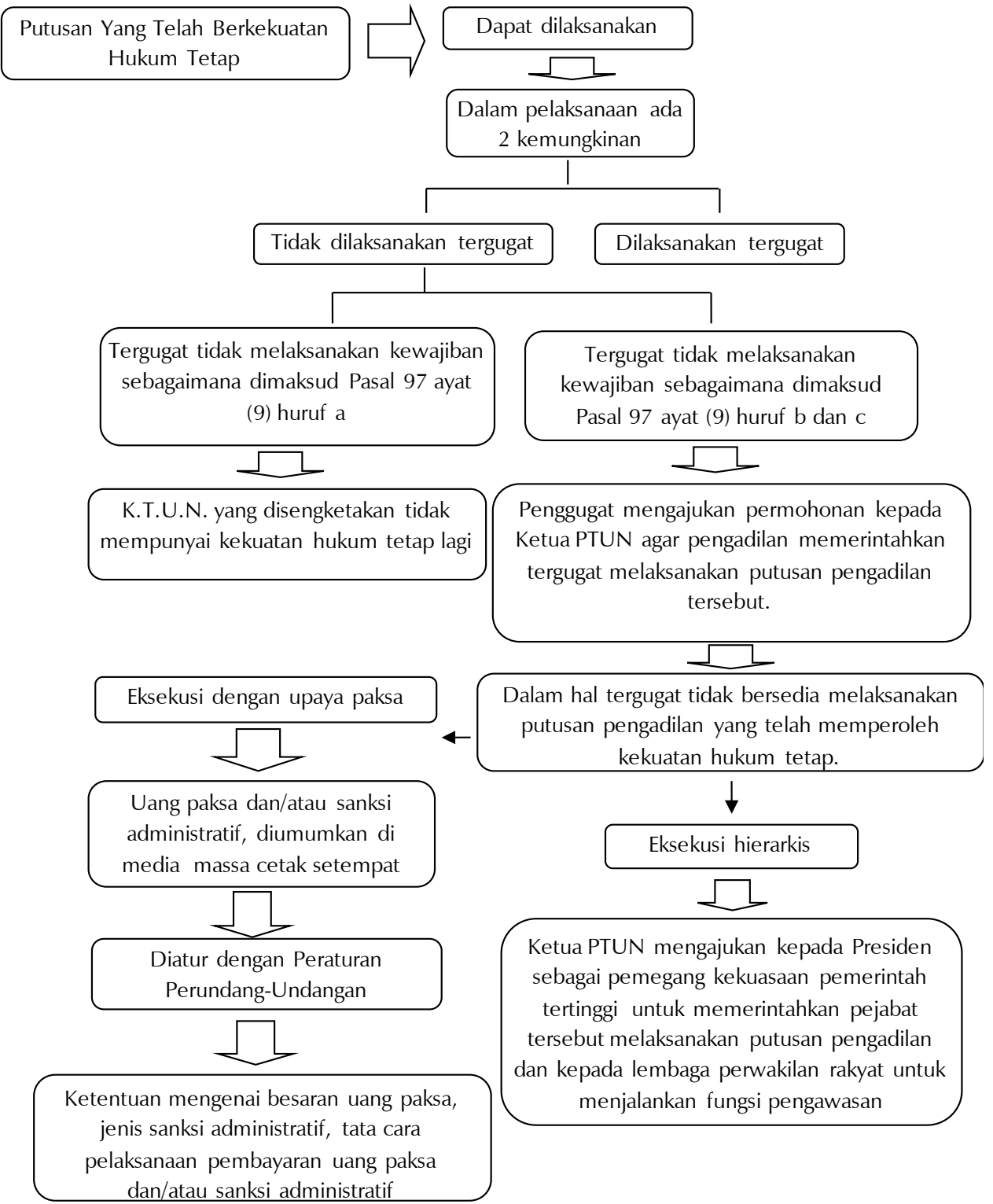

Gambar 1. Alur putusan berkekuatan tetap hingga eksekusi

jiban sebagaimana dimaksud oleh Pasal 97 ayat (9) huruf b dan c setelah 90 hari kerja maka, undang-undang memperkenankan kepada penggugat untuk mengajukan permohonan kepada Ketua PTUN agar memerintahkan tergugat melaksanakan putusan pengadilan.

Dalam hal tergugat setelah diperintahkan untuk melaksanakan putusan ternyata tetap tidak melaksanakan, maka kepada pejabat yang bersangkutan dikenakan upaya paksa berupa pembayaran sejumlah uang paksadan/atau sanksi administratif serta diumumkan pada media massa cetak setempat.
Ini disebut eksekusi dengan upaya paksa. Disamping eksekusi dengan upaya paksa, dikenal juga eksekusi hierarkis. Terjadi dalam hal Ketua Pengadilan Tata Usaha Negara mengajukan kepada Presiden sebagai pemegang kekuasaan pemerintah tertinggi untuk memerintahkan pejabat tersebut melaksanakan putusan pengadilan, dan kepada lembaga Perwakilan Rakyat untuk menjalankan fungsi pengawasan.

Namun demikian penerapan ketentuan mengenai besaran uang paksa (dwangsom), jenis sanksi administratif, tata cara pelaksanaan pembayaran uang paksa 
dan/atau sanksi administratif masih menunggu peraturan perundang-undangan. Merujuk Pasal 611a ayat (1) Burgerlijke Rechtsvordering (Belanda), dwangsom adalah De rechter kan op vordering van een der partijen de wederpartij veroordelen tot betaling van een geldsom, dwangsom genaamd, voor het geval dat aan de hoofdveroordeling niet wordt voldaan, onverminderd het recht op schadevergoeding indien daartoe gronden zijn, Een dwangsom kan echter niet worden opgelegd in geval van een veroordeling tot betaling van een geldsom, maksudnya adalah: atas tuntutan dari salah satu pihak, hakim dapat menghukum pihak lainnya untuk membayar sejumlah uang, yang disebut uang paksa dalam hal hukuman pokok tidak dilaksanakan, dengan tidak mengurangi hak ganti rugi dalam hal itu berdasar. (Tumpa, 2010: 17). Dari rumusan pasal tersebut dapat disimpulkan bahwa uang paksa merupakan hukuman yang diberikan oleh hakim karena hukuman pokok tidak dilaksanakan.

Karena tidak taatnya pihak yang kalah untuk secara sukarela melaksanakan putusan pengadilan, maka ada sanksi uang paksa. Jika putusan pengadilan dilaksanakan secara sukarela maka tidak ada hukuman uang paksa. Terkait dengan ini adalah uang paksa (dwangsom) bersifat accessoir, artinya hukuman yang mengikut pada hukuman pokok. Sehingga tidak mungkin suatu hukuman uang paksa tanpa ada hukuman pokok, tetapi tidak selalu hukuman pokok harus selalu diikuti hukuman uang paksa.

Sifat uang paksa selain accessoir merupakan hukuman tambahan dan sebagai tekanan psychis bagi terhukum. Uang paksa sebagai hukuman tambahan berarti apabila hukuman pokok yang ditetapkan oleh hakim tidak dipenuhi oleh tergugat dengan suka rela maka diperlakukanlah hukuman uang paksa. Uang paksa sebagai tekanan psychis bagi terhukum berarti dengan adanya hukuman uang paksa yang ditetapkan oleh hakim, maka pihak yang kalah ditekan secara psychis agar ia secara sukarela memenuhi hukuman pokok yang telah ditetapkan oleh ha$\mathrm{kim}$. Untuk sifat yang ini penulis berpendapat termasuk sifat preventif dari hukuman uang paksa. Karena dari pada dijatuhi hukuman uang paksa lebih baik melaksanakan putusan pengadilan secara sukarela.

Pasal 80 sampai dengan Pasal 84 Undang-Undang Nomor 30 Tahun 2014 tentang Administrasi Pemerintahan mengatur jenisjenis sanksi administratif dan pejabat yang berwenang menjatuhkan sanksi administratif. Menjadi persoalan adalah apakah undangundang ini dapat menjadi dasar hukum bagi hakim untuk menjatuhkan sanksi administrasi secara langsung kepada tergugat?

Hasil penelitian Peneliti ke Pengadilan Tata Usaha Negara Jakarta, Pengadilan Tata Usaha Negara Bandung, Pengadilan Tata Usaha Negara Yogyakarta diperoleh data seperti ditunjukkan pada Tabel 1.

Tabel 1. Jumlah Permohonan Eksekusi

\begin{tabular}{ccccc}
\hline \multirow{2}{*}{ No } & \multirow{2}{*}{ Tahun } & \multicolumn{3}{c}{$\begin{array}{c}\text { Jumlah Permohonan Eksekusi } \\
\text { Kepada Ketua PTUN }\end{array}$} \\
\cline { 3 - 5 } & & Jakarta & Yogyakarta & Bandung \\
\hline 1 & 2013 & 14 & & 42 \\
2 & 2014 & 9 & & 11 \\
3 & 2015 & 17 & 1 & 3 \\
4 & 2016 & 17 & 5 & 12 \\
\hline
\end{tabular}

Sumber: diolah dari data sekunder

Permohonan eksekusi dilakukan oleh penggugat karena tergugat tidak secara sukarela melaksanakan putusan Peradilan Tata Usaha Negara yang telah berkekuatan hukum tetap secara sukarela. Hal ini menunjukkan lemahnya kesadaran badan atau pejabat tata usaha Negara untuk secara sukarela melaksanakan putusan Peradilan Tata Usaha Negara yang telah berkekuatan hukum tetap. (Untoro, 2014: 70). Idealnya adalah putusan yang telah memperoleh kekuatan hukum tetap dilaksanakan oleh badan atau pejabat tata usaha Negara sebagai tergugat tanpa didahului dengan permohonan. Permohonan eksekusi seperti tampak dalam tabel dari penggugat kepada Ketua Pengadilan Tata Usaha Negara Jakarta dan Bandung dan Yogyakarta.

Terjadinya permohonan untuk melaksanakan putusan Peradilan Tata Usaha Negara karena tergugat tidak secara sukarela melaksanakan kewajiban yang telah diputuskan, yaitu pertama: pencabutan Keputusan Tata Usaha Negara yang bersangkutan atau yang 
disengketakan dan menerbitkan Keputusan Tata Usaha Negara yang baru. Kedua, Penerbitan Keputusan Tata Usaha Negara dalam hal gugatan didasarkan pada Pasal 3 UndangUndang Nomor 5 Tahun 1986 tentang Peradilan Tata Usaha Negara.

Problem eksekusi putusan Pengadilan Tata Usaha Negara yang telah berkekuatan hukum tetap merupakan fenomena hukum yang bersifat umum, termasuk di beberapa negara juga menghadapi persoalan ini. Karena tidak tersedia upaya paksa dari segi yuridis yang cukup efektif untuk dapat memaksakan badan atau pejabat Tata Usaha Negara untuk mentaati putusan Pengadilan Tata Usaha Negara. (Supandi. 2014). Berdasar hasil penelitian sebelumnya dengan perbandingan negara Thailand diperoleh analisis bahwa konsep penting yang digunakan Thailand untuk mengefektifkan upaya paksa pelaksanaan putusan Peradilan Tata Usaha Negara merupakan konsep sebagai bentuk ketegasan dalam mewujudkan jaminan kepastian akses keadilan administrative bagi warga negaranya. Konsep yang pertama, mengenai kewenangan peradilan administrasi Thailand untuk melaksanakan eksekusi rill terhadap putusan peradilan administrasi yaitu dengan menggunakan Hukum Acara Perdata secara mutatis mutandis terhadap harta kekayaan pejabat tata usaha Negara yang mengabaikan putusan peradilan. Jadi dengan konsep ini eksekusi riil terhadap harta pribadi pejabat bukan harta atau keuangan Negara. Konsep kedua, Tersedianya mekanisme contempt of court bagi pejabat tata usaha negara yang tidak mematuhi perintah peradilan dengan diberikan sanksi berupa sanksi paksaan atau menetapkan tindakan disipliner terhadap pejabat tata usaha Negara yang bersangkutan ataun tanpa pemeriksaan pengadilan menjatuhkan hukuman penjara dengan alasan contempt of court. (Jiwantara dan Wibowo, 2014).

Di Indonesia belum dikenal konsep contempt of court, namun demikian dengan telah diundangkannya Undang-Undangn Nomor 30 Tahun 2014 tentang Administratif Pemerintahan, dikenal keputusan fiktif positif, sebagaimana diatur dalam Pasal 53. Se- hingga kewajiban yang harus dilakukan oleh tergugat adalah menerbitkan Keputusan Tata Usaha Negara dalam hal gugatan didasarkan pada Pasal 53. Pasal 3 ayat (2) Undang-Undang Nomor 5 Tahun 1986 tentang Peradilan Tata Usaha Negara mengatur tentang Keputusan Tata Usaha Negara fiktif negatif yaitu jika suatu Badan atau Pejabat Tata Usaha Negara tidak mengeluarkan keputusan yang dimohon sedangkan jangka waktu telah lewat, maka badan atau pejabat tata usaha negara dianggap telah menolak mengeluarkan keputusan yang dimaksud. Lahirnya Undang- Undang Nomor 30 Tahun 2014 tentang Administratif Pemerintahan, bagi jajaran Peradilan Tata Usaha Negara dapat sebagai landasan melakukan jihad judicial dan bagi peziarah keadilan (justitia belen) dapat digunakan akses memperoleh keadilan atau access to justice (Permana, 2015: 421).

Jangka waktu untuk mengeluarkan keputusan yang dimohonkan telah lewat merupakan acuan untuk menentukan sebuah keputusan disebut keputusan fiktif negatif yaitu baik yang secara jelas telah ditentukan dalam peraturan perundang-undangan maupun yang tidak ditentukan dalam peraturan perundang-undangan.

Sementara itu, waktu yang tidak ditentukan dalam peraturan perundang-undangan, jangka waktunya adalah setelah 4 bulan sejak diterima permohonan. Pasal 3 ayat (3) Undang-Undang Nomor 5 Tahun 1986 menyatakan dalam hal peraturan perundang-undangan yang bersangkutan tidak menentukan jamgka waktu sebagaimana dimaksud dalam ayat (2), maka setelah lewat jangka waktu empat bulan sejak diterimanya permohonan, badan atau Pejabat Tata Usaha Negara yang bersangkutan dianggap telah mengeluarkan keputusan penolakan. Dengan kata lain faktor keberhasilan dalam pelaksanaan putusan pengadilan tata usaha negara yang telah berkekuatan hukum tetap sangat bergantung pada wibawa pengadilan tata usaha negara dan kesadaran hukum para pejabat itu sendiri (Mahkamah Agung RI, 2011: 384).

Adapun hambatan yang dihadapi oleh Pengadilan Tata Usaha Negara untuk mewu- 
judkan pemerintahan yang bersih dan berwibawa, pertama: tidak adanya lembaga khusus untuk melaksanakan putusan pengadilan; kedua, rendahnya kesadaran pejabat Tata Usaha Negara dalam menaati putusan PTUN; ketiga, tidak adanya ketentuan yang lebih rinci yang mengatur sanksi apabila putusan PTUN yang telah berkekuatan hokum tetap tidak dilaksanakan (Lubna, 2015: 170).

Ketaatan badan atau pejabat tata usaha negara untuk melaksanakan putusan Pengadilan Tata Usaha Negara yang telah memperoleh kekuatan hukum tetap membantu mewujudkan kepastian hukum bagi masyarakat pencari keadilan. Dimana kepastian hukum adalah merupakan salah satu dari asas-asas umum pemerintahan yang baik sebagaimana dimaksud oleh Undang-Undang Nomor 28 Tahun 1999 tentang Penyelenggara Negara yang Bersih dan Bebas dari Korupsi, Kolusi, dan Nepotisme. Asas-asas umum pemerintahan yang baik ini dimaksudkan sebagai peningkatan perlindungan hukum bagi rakyat dari tindakan administrasi negara yang menyimpang (verhoogde rechtsbescherming).

Karena Negara Republik Indonesia sebagai negara yang berdasar hukum (rechtstaat), maka sangat tepat apabila perbuatan pemerintah harus didasarkan atas hukum yang berlaku. Oleh karena itu terkait dengan tujuan negara sebagaimana dimaksud dalam pembukaan UUD 1945 alinea empat, maka agar perbuatan pemerintah selalu dalam kerangka menuju pada peningkatan kesejahteraan warganya, maka diperlukan enam bentuk pengawasan (Mahkamah Agung RI. 2011: 56), yaitu:

1. Pengawasan konstitutif (Constitutional control).

2. Pengawasan politik (Political control).

3. Pengawasan yuridis dan legalitas (Judicial and legal control).

4. Pengawasan teknik (Tehnical control).

5. Pengawasan sosial (Social control).

6. Pengawasan administratif (Administrative control).

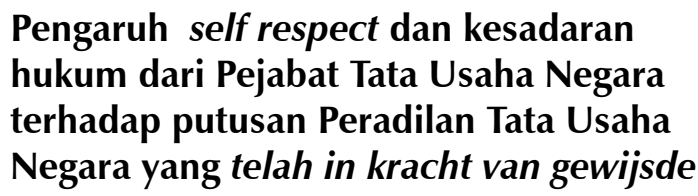

\section{bagi terwujudnya keadilan.}

Putusan hakim dilihat dari segi ontologi mempunyai obyek studi sendiri, yaitu penerapan hukum pada fakta yang bermuatan penyelesaian definitif terhadap suatu sengketa yang ditimbulkan oleh fakta atau fakta-fakta tersebut (Rivai, 2014: 92-93). Oleh karena itu agar vonis dapat memberikan penyelesaian definitif terhadap sengketa, maka vonis itu harus mampu menyakinkan bahwa vonis tersebut adalah sebuah putusan yang dihasilkan melalui proses pengambilan keputusan yang imparsial, obyektif, adil, dan manusiawi sehingga dapat diterima atau akseptabel oleh para pihak terkait dan oleh masyarakat umum.

Putusan hakim yang telah berkekuatan hukum tetap jika tidak dilaksanakan oleh tergugat, berarti tidak bermanfaat dan tidak memiliki kepastian hukum. Padahal putusan hakim merupakan hukum atau undang-undang yang mengikat antara pihak yang bersangkutan. Oleh karena itu sudah sewajarnya tergugat secara sukarela melaksanakan putusan Peradilan Tata Usaha Negara. Mengingat bahwa dalam sebuah putusan hakim telah mermuat 3 hal yang merupakan argumentasi hukum dalam putusan hakim: hukum sebagai putusan yang memiliki otoritas (positivitas); hukum sebagai tatanan (koherensi). 3. Hukum sebagai pengaturan hubungan antar manusia yang tepat (keadilan); dan argumentasi hukum ini dalam asasnya semuanya menuntut suatu klaim pada putusan hakim. Klaim yang dimaksud adalah bahwa setiap putusan hakim harus bermuatan tiga hal yang merupakan cita hukum yaitu: positivitas, koherensi, keadilan.

Bagi penggugat bisa saja mengalami dua kali ketidakadilan karena belum optimalnya self respect dan kesadaran hukum dari Pejabat Tata Usaha Negara yaitu pertama ketika menerima Keputusan Tata Usaha Negara yang merugikan kepentingannya. Kedua, pada saat penggugat mengajukan permohonan kepada Ketua Pengadian Tata Usaha Negara agar tergugat melaksanakan putusan pengadilan tersebut. Padahal penggugat telah menjalani proses persidangan yang memakan waktu lama dan dinyatakan sebagai 
pemenang, penggugat masih harus membayar mahal agar dapat menikmati kemenangannya.

Setiap orang menghendaki hukum dilaksanakan dan ditegakkan, bagaimana hukumnya itulah yang harus berlaku. Dengan ungkapan meskipun dunia ini runtuh hukum harus ditegakkan (fiat justitia et pereat mundus. Keadaan inilah yang diinginkan oleh kepastian hukum. Kepastian hukum sangat mengandalkan ketentuan-ketentuan hukum yang terkodifikasi, hal ini mengandung maksud untuk menjamin kepastian hukum (legal certainty) dalam arti bahwa hukum tertulis telah mengatur sanksi terhadap perbuatanperbuatan tertentu. Peraturan hukum untuk memastikan dan menjamin prediktabilitas, sehingga orang tidak melakukan perbuatan yang diancam dalam peraturan tersebut (Samekto, 2015: 91-92).

Karena dengan adanya kepastian hukum masyarakat akan lebih tertib. Disamping itu masyarakat mengharapkan manfaat dan keadilan dalam pelaksanaan atau penegakan hukum. Oleh karena itu hukum harus memuat 3 nilai dasar, yaitu keadilan (nilai filosofis), kepastian hukum (nilai yuridis) dan kemanfaatan (nilai sosiologis). Dengan demikian diharapkan akan tercapai tujuan dari hukum, yaitu: mewujudkan keadilan, kemanfaatan dan kesejahteraan hidup.

Disinilah pentingnya penghargaan diri (self respect) dan ketaatan badan atau pejabat tata usaha negara untuk melaksanakan putusan Pengadilan Tata Usaha Negara yang telah memperoleh kekuatan hukum tetap membantu mewujudkan kepastian hukum bagi masyarakat pencari keadilan.

Asas kepastian hukum adalah asas dalam negara hukum yang mengutamakan landasan peraturan perundang-undangan, kepatuhan, dan keadilan dalam setiap kebijakan penyelenggaraan Negara. Asas kepastian hukum merupakan salah satu dari asas-asas umum pemerintahan yang baik sebagaimana dimaksud oleh Undang-Undang Nomor 28 Tahun 1999 tentang Penyelenggara Negara yang Bersih dan Bebas dari Korupsi, Kolusi, dan Nepotisme. Asas-asas umum pemerintahan yang baik ini dimaksudkan sebagai pe- ningkatan perlindungan hukum bagi rakyat dari tindakan administrasi negara yang menyimpang (verhoogde rechtsbescherming). Arti penting kesadaran pejabat tata usaha negara disampaikan juga oleh Firzhal Arzhi Jiwantara dan Gatot Dwi Hendro Wibowo bahwa ada tiga faktor yang menyebabkan lemahnya eksekusi putusan Pengadilan Tata Usaha Negara yang telah berkekuatan hukum tetap. Pertama, tidak adanya aturan hukum yang memaksa bagi pejabat tata usaha negara untuk melaksanakan putusan Pengadilan Tata Usaha Negara yang telah berkekuatan hukum tetap. Kedua, tidak dicantumkannya pembayaran uang paksa dalam amar putusan bagi pejabat yang tidak melaksanakan putusan Pengadilan Tata Usaha Negara yang telah berkekuatan hukum tetap. Ketiga, faktor kepatuhan pejabat tata usaha Negara untuk melaksanakan putusan Pengadilan Tata Usaha Negara yang telah berkekuatan hukum tetap.

Demikian juga apa yang disampaikan oleh Ismail Rumadhan bahwa terdapat tiga masalah yang mempengaruhi terjadinya eksekusi putusan Peradilan Tata Usaha Negara. Pertama, mekanisme eksekusi yang ditempuh masih mengambang. Kedua, permasalahan penerapan uang paksa. Kepada siapa uang paksa dibebankan, berapa jumlah nominal uang paksa yang dibebankan, sumber pembiayaan uang paksa apabila dibebankan kepada Badan Tata Usaha Negara. Ketiga adalah otonomi daerah. Bahwa bupati atau walikota sebagai pejabat tata usaha negara yang merasa bukan bawahan Gubernur. Pemberlakuan otonomi daerah membawa konsekuensi seluruh pejabat di Kabupatan/ Kota mempunyai kewenangan menerbitkan keputusan berkaitan dengan pengelolaan daerahnya. (Puslitbang Hukum dan Peradilan Badan Litbang Kumdil MA RI, 2010: vii).

Di sisi lain pentingya sanksi delik mengenai penyelenggaraan peradilan atau contempt of court dapat diterapkan dalam upaya pembentukan self respect dan kesadaran hukum Pejabat Tata Usaha Negara. Bentuk dari contempt of court diantaranya adalah pemidanaan terhadap orang yang tidak mentaati perintah pengadilan yang dapat merendah- 
kan kekuasaan, kewibawaan dan kehormatan pengadilan. Dari hasil kuesioner terhadap 100 orang yang terdiri dari para pihak yang bersengketa dan pengunjung sidang pada Pengadilan TataUsaha Negara Jakarta bulan Oktober 2015 diperoleh jawaban 74,13\% menghendaki penerapan sanksi pidana bagi pejabat yang tidak mematuhi putusan PTUN (Permana, 2015: 90).

Istilah contemt of court terdapat dalam penjelasan umum Undang-Undang Nomor 14 Tahun 1985 tentang Mahkamah Agung, dinyatakan bahwa "Selanjutnya untuk dapat lebih menjamin terciptanya suasana yang sebaik-baiknya bagi penyelenggaraan peradilan guna menegakkan hukum dan keadilan berdasarkan Pancasila, maka perlu dibuat suatu undang-undang yang mengatur penindakan terhadap perbuatan, tingkah laku, sikap dan atau ucapan yang dapat merendahkan dan merongrong kewibawaan, martabat dan kehormatan badan peradilan yang dikenal sebagai contempt of court.

Mengutip pendapat Sjahran Basah menyatakan dalam kaitannya Peradilan Tata Usaha Negara sebagai salah satu badan peradilan yang menjalankan fungsi kekuasaan kehakiman yang bebas dan sederajat dengan badan peradilan lainnya, mempunyai konsekuensi memberikan perlindungan maupun pengayoman hukum bagi para pihak. Sehingga Peradilan Tata Usaha Negara dalam memberikan perlindungan maupun pengayoman bermanfaat sebagai:

1. Tindakan pembaharuan bagi perbaikan pemerintah untuk kepentingan rakyat.

2. Stabilisator hukum dalam pembangunan.

3. Pemelihara dan peningkat keadilan dalam masyarakat.

4. Penjaga keseimbangan antara kepentingan perseorangan dan kepentingan umum.

Lebih lanjut Sjahran Basah menyatakan tujuan Pengadilan Administrasi atau dalam kaidah hukum positif disebut Peradilan Tata Usaha Negara untuk memberikan pengayoman hukum dan kepastian hukum bagi rakyat dan administrasi negara dalam arti menjaga dan memelihara keseimbangan kepentingan masyarakat dengan kepentingan individu. Bagi administrasi negara akan ter- jaga ketertiban, ketentraman dan keamanan dalam melaksanakan tugas-tugasnya demi terwujudnya pemerintahan yang bersih dan berwibawa dalam negara hukum berdasarkan Pancasila.

Relevan dengan itu ada 5 karakteristik negara hukum Pancasila, yaitu:

1. Merupakan negara kekeluargaan, di dalamnya terdapat pengakuan terhadap hak-hak individu (termasuk hak milik) atau hak asasi manusia namun dengan tetap mengutamakan kepentingan nasional (kepentingan bersama) di atas kepentingan bersama.

2. Negara hukum yang berkepastian dan berkeadilan dengan sifatnya yang prismatik maka konsep negara hukum Pancasila dalam kegiatan berhukum baik dalam proses pembentukan maupun pengimplementasiannya dilakukan dengan memadukan berbagai unsur yang baik yang terkandung dalam konsep rechtstaat maupun the rule of law yakni dengan memadukan antara prinsip kepastian hukum dengan prinsip keadilan, serta konsep dan sistem hukum lain, misalnya sistem hukum adat dan sistem hukum agama yang hidup di nusantara ini, sehingga terciptalah suatu prasarat bahwa kepastian hukum harus ditegakkan demi menegakkan keadilan dalam masyarakat sesuai dengan prinsip-prinsip Pancasila.

3. Merupakan religious nation state. Dengan melihat pada hubungan antara negara dengan agama maka konsep negara hukum Pancasila tidaklah menganut sekulerisme tetapi juga bukanlah sebuah Negara agama. Konsep Negara hukum Pancasila adalah sebuah konsep Negara yang berketuhanan dalam arti bahwa kehidupan berbangsa dan bernegara Indonesia didasarkan atas kepercayaan kepada Ketuhanan Yang Maha Esa, dengan begitu maka terbukalah suatu kebebasan bagi warga Negara untuk memeluk agama dan kepercayaan sesuai keyakinan masing-masing.

4. Memadukan hukum sebagai sarana perubahan masyarakat dan hukum sebagai cermin budaya masyarakat. Dengan memadukan kedua konsep ini 
negara hukum Pancasila mencoba untuk memelihara dan mencerminkan nilainilai yang hidup dalam masyarakat (living law) sekaligus pula melakukan positivisasi terhadap living law tersebut untuk mendorong dan mengarahkan masyarakat pada perkembangan dan kemajuan yang sesuai dengan prinsip-prinsip Pancasila.

5. Basis pembuatan dan pembentukan hukum nasional haruslah didasarkan pada prinsip hukum yang bersifat netral dan universal, dalam pengertian bahwa harus memenuhi persyaratan utama yaitu Pancasila sebagai perekat dan pemersatu; berlandaskan nilai yang dapat diterima oleh semua kepentingan dan tidak mengistimewakan kelompok atau golongan tertentu; mengutamakan prinsip gotong royong dan toleransi; serta adanya kesamaan visi-misi, tujuan dan orientasi yang sama disertai dengan saling percaya (Mahfud MD. 2006: 23-30).

\section{Simpulan}

Berdasarkan uraian-uraian pada babbab tersebut di atas, maka kesimpulannya adalah sebagai berikut: Pertama, ada tiga faktor yang menjadi penyebab tidak dipatuhinya putusan Peradilan Tata Usaha Negara in kracht van gewijsde yaitu: regulasi eksekusi putusan Peradilan Tata Usaha Negara, kualitas putusan Peradilan Tata Usaha Negara, budaya hukum Pejabat Tata Usaha Negara. Kedua, self respect dan kesadaran hukum Pejabat Tata Usaha Negara terhadap putusan Peradilan Tata Usaha Negara yang yang telah in kracht van gewijsde berpengaruh dalam mewujudkan keadilan. Putusan hakim yang telah berkekuatan hukum tetap jika tidak dilaksanakan oleh tergugat, berarti tidak bermanfaat dan tidak memiliki kepastian hukum. Padahal putusan hakim merupakan hukum atau undang-undang yang mengikat antara pihak yang bersangkutan. Oleh karena itu sudah sewajarnya tergugat harus secara sukarela melaksanakan putusan Peradilan Tata Usaha Negara yang telah berkekuatan hukum tetap. Karena dengan adanya kepastian hukum masyarakat akan lebih tertib. Di samping itu masyarakat mengharapkan manfaat dan keadilan dalam pelaksanaan atau penegakan hukum. Oleh karena itu hukum harus memuat 3 nilai dasar, yaitu keadilan (nilai filosofis), kepastian hukum (nilai yuridis) dan kemanfaatan (nilai sosiologis). Dengan demikian diharapkan akan tercapai tujuan dari hukum, yaitu: mewujudkan keadilan, kestabilan dan kesejahteraan hidup.

\section{Daftar Pustaka}

Bakti, T. S. (2016). Politik Hukum dalam Putusan Hakim. Jurnal Hukum dan Peradilan, 5(1), 53-72. Dalam https://scholar.google.co.id/ scholar?hl=id\&as_sdt $=0 \% 2 \mathrm{C} 5 \& \mathrm{q}=$ Politik $+\mathrm{H}$ ukum + dalam + Putusan + Hakim.\&btnG $=$. Diunggah pada 28 Juli 2018.

Effendi, M. (2018). Peradilan Tata Usaha Negara Indonesia Suatu Pemikiran Ke Arah Perluasan Kompetensi Pasca Amandemen Kedua Undang-Undang Peradilan Tata Usaha Negara. Jurnal Hukum dan Peradilan, 3(1), 25-36. Dalam https://scholar.google.co.id/scholar?hl=id\&as_ $\mathrm{sdt}=0 \% 2 \mathrm{C} 5 \& \mathrm{q}=$ Peradilan $+\mathrm{Tata}+$ Usaha $+\mathrm{Ne}$ gara +Indonesia + Suatu + Pemikiran + Ke + Ara $\mathrm{h}+$ Perluasan + Kompetensi + Pasca + Amandem en +Kedua + Undang-Undang + Peradilan + Ta ta + Usaha + Negara\&btnG $=$ Diunggah pada 28 Juli 2018.

Hadjon, P. M. (2015). Peradilan Tata Usaha Negara Dalam Konteks Undang-Undang Nomor 30 Tahun 2014 tentang Adminitrasi Pemerintahan. Jurnal Hukum dan Peradilan, 4(1), 51-64.Dalam https://scholar.google.co.id/scholar?hl=id\&as $\mathrm{sdt}=0 \% 2 \mathrm{C} 5 \& \mathrm{q}=$ Peradilan $+\mathrm{Tata}+$ Usaha $+\mathrm{Ne}$ gara +Dalam + Konteks + Undang-Undang $+\mathrm{No}$ mor + 30+Tahun +2014+tentang +Adminitra si + Pemerintahan.\&btnG $=$ Diunggah pada 24 Juli 2018.

Heriyanto, Bambang. 2014. Bunga Rampai Peradilan Administrasi Kontemporer. Sanksi of Court Dalam Lembaga Eksekusi Peradilan Tata Usaha Negara. Yogyakarta: Genta Press.

Jiwantara, Firzhal Arzhi dan Gatot Dwi Hendro Wibowo. 2014"Kekuatan Eksekutorial Putusan PTUN dan Implikasi Dalam Pelaksanaannya". httpjurnalius.ac.idojsindex.phpjurnalIUSarticleviewFile164140 (Diunduh tanggal, 7 Juli 2018.

Lubna, L. (2015). Upaya Paksa Pelaksanaan Putusan Pengadilan Tata USAha Negara Dalam Memberikan Perlindungan Hukum Kepada Masyarakat. Jurnal IUS Kajian Hukum dan Keadilan, 3(1). Dalam https://scholar.google.co.id/ scholar?hl=id\&as_sdt $=0 \% 2 \mathrm{C} 5 \& \mathrm{q}=$ Upaya $+\mathrm{Pa}$ ksa + Pelaksanaan+ Putusan + Pengadilan + Tata + USAha + Negara +Dalam + Memberikan+Per lindungan + Hukum + Kepada + Masyarakat\&bt $\mathrm{nG}=$

Mahkamah Agung RI. 2011. Perkembangan Peradilan Tata Usaha Negara Dan Pokok-Pokok Hukum Tata Usaha Negara Dilihat Dari Beberapa Sudut Pandang. Jakarta: Perpustakaan dan Layanan Informasi Biro Hukum dan Humas Badan Urusan Administrasi Mahkamah agung Republik Indonesia. 
Moh. Mahfud, MD., 2006. Membangun Politik Hukum Menegakkan Konstitusi. Jakarta: Pustaka LP3S.

Neno, Victor Yaved. 2006. Implikasi Pembatasan Kompetensi Absolut Peradilan Tata Usaha Negara. Bandung: Citra Aditya Bakti.

Permana, T. C. I. (2015). Peradilan Tata Usaha Negara Pasca Undang-Undang Administrasi Pemerintahan Ditinjau Dari Segi Access To Justice. Jurnal Hukum Dan Peradilan, 4(3), 419-442. Dalam https://scholar.google.co.id/scholar?hl=id\&as $\mathrm{sdt}=0 \% 2 \mathrm{C} 5 \& \mathrm{q}=$ Peradilan + Tata + Usaha $+\mathrm{Neg}$ ara + Pasca + Undang-Undang + Administrasi $+P$ emerintahan +Ditinjau +Dari+Segi + Access $+\mathrm{T}$ o+Justice\&btnG = Diungguh pada 24 Juli 2018

Permana, Tri Cahya Indra. 2016. Catatan Kritis Terhadap Perluasan Kewenangan Mengadili Peradilan Tata Usaha Negara. Yogyakarta: Genta Press.

Permana, Tri Cahya Indra. Ismail Rumadhan. Bestian Panjaitan. Mariyam Sugiarti. 2015. Urgensi Pengaturan (lus Constituendum) Eksekutabilitas Putusan TUN Yang Telah Berkekuatan Hukum Tetap Untuk Menjamin Kepatuhan Pejabat TUN. DIPA 2015. Puslitbang Hukum Dan Peradilan Badan Litbang Diklat Kumdil Mahkamah Agung RI, Bogor.

Ridwan HR., 2014. Hukum Administrasi Negara. Jakarta: PT RajaGrafindo Persada.

Rivai, Yulius. 2014. Bunga Rampai Peradilan Administrasi Kontemporer. Putusan Hakim Sebagai Suatu Ilmu. Yogyakarta: Genta Press.

Rumadan, Ismail. (2012). Problematika Eksekusi Putusan Pengadilan Tata Usaha Negarta. Jurnal Hukum dan Peradilan, 1(3), 435-462. Dalam https://scholar.google.co.id/scholar?hl=id\&as $\mathrm{sdt}=0 \% 2 \mathrm{C} 5 \& \mathrm{q}=$ Problematika + Eksekusi + Put usan + Pengadilan + Tata + Usaha + Negarta.\&bt $\mathrm{nG}=$ Diunduh pada 27 Juli 2018.

Samekto, Adji, 2015. Pergeseran Pemikiran Hukum Dari Era Yunani Menuju Postmodernisme. Jakarta: Konstitusi Press.

Simanjuntak, Enrico, 2014, "Prospek Ombudsman Republik Indonesia Dalam Rangka Memperkuat Pelaksanaan Eksekusi Putusan Peradilan Tata Usaha Negara". httpoaji.netarticles20163905-1474344518.pdf (Diunduh tanggal 7 Juli 2018) .

Sulaiman, Abdullah, 2006. Metode Penulisan IImu Hukum. Jakarta: Program Magister Ilmu Hukum Pascasarjana Universitas Islam Jakarta.

Supandi, 2016, Hukum Peradilan Tata Usaha Negara.
Bandung: Alumni.

Supandi. 2004, Problematika Penerapan Eksekusi Putusan Peradilan TUN Terhadap Pejabat TUN Daerah. Makalah disampaikan dalam Workshop tentang Penerapan Eksekusi Putusan PTUN Dalam Kaitannya dengan Pelaksanaan Otonomi Daerah. LPP-HAN bekerjasama dengan $\mathrm{KNH}$., Jakarta.

Susilo, A. B. (2015). Makna dan kriteria diskresi Keputusan dan/atau tindakan pejabat publik dalam mewujudkan tata pemerintahan yang baik. Jurnal Hukum dan Peradilan, 4(1), 133-152. https://scholar.google.co.id/scholar?hl=id\&as $\mathrm{sdt}=0 \% 2 \mathrm{C} 5 \& \mathrm{q}=$ Makna + dan + kriteria + diskre si +Keputusan + dan\%2Fatau+tindakan + pejab at + publik + dalam + mewujudkan + tata + peme rintahan + yang + baik.\&btnG $=$ Diunduh pada 24 juli 2018.

Tumpa, Harifin A., 2010, Memahami Eksistensi Uang Paksa (Dwangsom) Dan Implementasinya Di Indonesia. Jakarta: Kencana.

Untoro, Fatimah dan Hamdan Azhar Siregar. (2014). "Efektifitas Ketentuan Pelaksanaan Putusan Pengadilan Tata Usaha Negara Yang telah Memperoleh Kekuatan Hukum Tetap". Jurnal Reformasi Hukum. XVIII (1): 51-74. Jakarta: Universitas Islam Jakarta.

Wahyunadi, Y. M. (2016). Kompetensi Absolut Pengadilan Tata Usaha Negara Dalam Konteks Undang-Undang Nomor 30 Tahun 2014 Tentang Administrasi Pemerintahan. Jurnal Hukum dan Peradilan, 5(1), 135-154. Dalam https://scholar.google.co.id/scholar?hl=id\&as $\mathrm{sdt}=0 \% 2 \mathrm{C} 5 \& \mathrm{q}=$ Kompetensi + Absolut + Penga dilan+Tata +Usaha + Negara+Dalam + Kontek $\mathrm{s}+$ Undang-Undang +Nomor $+30+$ Tahun +20 $14+$ Tentang + Administrasi + Pemerintahan\&b $\operatorname{tnG}=$ Diunduh pada 23 Juli 2018 .

\section{Peraturan Perundang-Undangan}

Undang-Undang Nomor 5 Tahun 1986 tentang Peradilan Tata Usaha Negara.

Undang-Undang 9 Tahun 2004 tentang Perubahan Atas Undang-Undang Nomor 5 Tahun 1986 tentang Peradilan Tata Usaha Negara.

Undang-Undang Nomor 51 Tahun 2009 tentang Perubahan Kedua Atas Undang-Undang Nomor 5 Tahun 1986 tentang Peradilan Tata Usaha Negara.

Undang-Undang Nomor 30 Tahun 2014 tentang Administrasi Pemerintahan. 